\title{
ANALISIS SOSIOPRAGMATIK PADA TINDAK TUTUR KOMUNITAS PEMAIN GAME ONLINE DI KOTA SOLO
}

\author{
Andreas Raymonda ${ }^{1}$; Djatmika ${ }^{2}$; Edi Subroto ${ }^{3}$ \\ ${ }^{1}$ Universitas Sebelas Maret, Surakarta, Indonesia \\ ${ }^{2,3}$ Professor in Linguistics at Universitas Sebelas Maret, Surakarta, Indonesia \\ a.raymonda@yahoo.com
}

\begin{abstract}
This paper was aimed to discuss speech act patterns in online gamer community and to uncover the details of specific terms used by that community, especially those found in Solo. Some approaches and theories about sociopragmatics were used for data analysis dealing with the types and functions of speech act as well as the specific terms used by that online gamer community stayed in Solo. By implementing context analysis method, data collected from participation observation technique, unstructured interview, and elicitation, speech act types from that community could be specified based on the frequency of usage. The highest to the lowest usage speech act types were directive, assertive, expressive, commisive, verdictive, and declarative. Noun was found as the most used class of words in specific terms and followed by the emerge of smaller percentage word class of verb, adjective, and adverb.
\end{abstract}

Key words: sosiopragmatics, speech act, specific term, online game community

\section{PENDAHULUAN}

Permainan tradisional, apabila dilihat dari kacamata kebudayaan, adalah salah satu hal yang sebenarnya harus dilestarikan keberadaannya. Banyak manfaat positif yang dapat diambil dari permainan tradisional tersebut; contoh pertama, permainan tradisional seperti engklek, betengan, gobak sodor, dan delikan yang memerlukan gerak tubuh dapat meningkatkan kemampuan fisik sekaligus motorik yang sangat bermanfaat bagi kesehatan tubuh; kedua, diperlukannya sejumlah anggota dalam setiap tim dalam permainan tradisional, secara tidak langsung dapat melatih anak-anak untuk bekerja secara tim dalam menyusun strategi; ketiga, sebagian besar permainan tradisional membutuhkan komunikasi antaranak yang pada akhirnya dapat meningkatkan kemampuan berbahasa dengan sangat efektif.

Meskipun begitu, ada juga kekurangan dari permainan tradisional yang dapat ditemukan. Beberapa kekurangan dari permainan tradisional antara lain: pertama, sangat 
tergantung pada kondisi cuaca karena betengan, rambatan, benthik, dan gobak sodor memerlukan tempat luas di luar rumah; kedua, kemampuan fisik yang prima dibutuhkan untuk turut serta dalam permainan tradisional, sehingga tidak mungkin apabila ada seorang anak yang sakit mengikuti salah satu dari permainan yang sudah disebutkan sebelumnya. Dua kekurangan, dan dimungkinkan ada kekurangan lain, permainan tradisional ini dapat menimbulkan keengganan dari anak untuk terus-menerus memainkannya, yang pada akhirnya dapat menyisihkan permainan tradisional dari saingan utamanya yaitu permainan modern.

Sebagian besar keuntungan permainan modern terletak pada tampilan dan kemasan permainan itu sendiri yang menyita perhatian tidak hanya anak-anak tetapi juga orang dewasa. Salah satu permainan modern yang sangat digemari saat ini adalah permainan komputer elektronik atau yang biasa disebut dengan PC game (Personal Computer game). PC game adalah salah satu tipe perangkat lunak terinstal di dalam hardisk komputer sebagai program yang dapat dimainkan dengan menggunakan keyboard, mouse, dan/atau periperal lainnya. Permainan elektronik komputer mempunyai keuntungan sebagai berikut: pertama, tidak membutuhkan gerak tubuh yang dapat membuat lelah pemainnya; kedua, mempunyai tampilan warna dan grafik yang menarik dan semakin sempurna dari masa ke masa; ketiga, adanya banyak fitur canggih dalam permainan elektronik komputer menimbulkan imajinasi seakanakan pemain ikut masuk ke dalam permainan tersebut; keempat, perpaduan suara, gambar, dan grafis dalam permainan ini memungkinkan berbagai tingkatan umur untuk turut serta memainkannya tanpa mempunyai anggapan bahwa permainan elektronik komputer hanya untuk anak-anak. Poin-poin ini tidak ada dalam permainan tradisional sehingga peralihan para pemain dari permainan tradisional dapat dipastikan akan berpindah pada permainan modern.

Kelebihan yang cukup banyak disebutkan di atas tidak berarti bahwa permainan elektronik komputer tidak mempunyai kekurangan. Bahkan sebaliknya, kekurangan dari permainan ini berbanding secara seimbang dengan kelebihannya, antara lain: pertama, cara memainkan permainan elektronik komputer yang tidak membutuhkan banyak gerak tubuh dapat menyebabkan berbagai macam penyakit seperti obesitas, pusing, kram otot, ambeyen, mata 
minus, dll; kedua, ditilik dari faktor ekonomi, permainan semacam ini membutuhkan banyak perangkat lunak (software) maupun keras (hardware) yang tidak murah harganya; ketiga, sebagian besar permainan komputer membutuhkan waktu yang sangat lama untuk menyelesaikannya dan dapat menimbulkan efek kecanduan; keempat, cara bermain yang tidak membutuhkan teman untuk berkomunikasi secara langsung sangat mungkin menimbulkan pribadi yang introvert dan terkesan tidak membutuhkan orang lain di sekitarnya.

Dalam penelitian ini, penulis memilih untuk mengambil salah satu bentuk permainan, yaitu permainan elektronik komputer sebagai tema yang akan dibahas lebih lanjut. Perkembangan permainan komputer yang sangat pesat di dua dekade belakangan ini menciptakan tampilan gambar yang dapat dikatakan hampir sempurna pada beberapa judul game terbaru. Faktor pembuatan karakter yang sangat mirip dengan manusia asli dan cerita yang mengiringi ditambah lagi penataan musik secara indah, tidak heran bila banyak anak di masa sekarang yang lebih condong memainkan permainan elektronik komputer daripada permainan tradisional.

Perkembangan permainan elektronik pada komputer saat ini semakin marak dengan bantuan koneksi internet (biasa disebut dengan online game) yang memungkinkan pemain terhubung satu sama lain meskipun berbeda wilayah tempat tinggal dan negara. Fenomena cara bermain yang berbeda ini menciptakan cara berkomunikasi yang berbeda pula karena keterbatasan bahasa pemakainya yang beragam antarwilayah dan negara. Mereka mempunyai cara sendiri dan menyusun bahasa dan istilah khusus di kalangan pemain game elektronik komputer (biasa disebut gamer), untuk berkomunikasi satu dengan lainnya di dunia maya. Bahasa yang mereka gunakan mempunyai sifat dan ciri khas yang unik. Adalah tugas bagi peneliti kebahasaan untuk mengungkapkan maksud dan pola dari bahasa dan istilah khusus tersebut untuk membantu pemahaman masyarakat awam terhadap komunitas gamer ini.

Bertolak dari uraian di atas, penulis bertujuan membahas pola tindak tutur di komunitas gamer, mengungkapkan seluk beluk penggunaan jenis dan fungsi tindak tutur pada komunitas tersebut beserta istilah khusus yang digunakan, khususnya di kota Solo. Penulis menggunakan 
pendekatan dan teori-teori yang berhubungan dengan sosiopragmatik, konteks, dan implikatur untuk mengolah data-data yang nantinya akan diperoleh terkait dengan tindak tutur gamer di kota Solo.

\section{TEORI DAN METODOLOGI}

Penelitian ini dapat dikategorikan dalam penelitian etnografi. Jenis penelitian dengan menggunakan etnografi bertujuan untuk meneliti perilaku sebuah grup pertukaran kebudayaan atau individual. Perilaku grup yang dimaksud dalam penelitian ini berupa komunitas unik di masyarakat kota Solo yang disebut dengan komunitas gamer.

Selain itu, penelitian ini juga bertipe penelitian kualitatif yang akan tampak pada pemerolehan data penelitian, pengumpulan data, analisis data, dan penyajian hasil analisis data (Muhadjir, 1990). Ciri khas penelitian kualitatif merupakan suatu penelitian untuk mendeskripsikan peristiwa, perilaku orang atau suatu keadaan pada tempat tertentu secara rinci dan mendalam dalam bentuk narasi.

Data penelitian ini dibedakan menjadi dua, yaitu data primer (data utama) dan data sekunder (data penunjang). Data primer pada penelitian ini adalah tuturan para gamer yang di dalamnya mengandung jenis-jenis tindak tutur tertentu yang dapat dikelompokkan sesuai teori tindak tutur yang digunakan penulis, yaitu milik Searle dan Kreidler. Tuturan sebagai data primer tersebut diperoleh dari hasil observasi penulis pada komunitas gamer yang berwujud rekaman (sebagai sumber data) pada saat para gamer memainkan game online, wawancara dengan gamer, catatan lapangan, dan kuesioner. Data sekunder pada penelitian ini adalah hasil survey dan referensi mengenai game dari majalah dan internet yang akan penulis gunakan untuk menentukan peringkat game terbaik dan sering dimainkan oleh para gamer. Selain itu, penulis juga mendapatkan data penelitian dari penjaga pusat game online sebagai informan dan fitur chat online pada setiap game yang dapat dimainkan dengan fasilitas internet. Dengan bantuan 
data sekunder, penulis akan dimudahkan untuk menyortir game online apa saja yang akan dipilih dan dibahas dalam penelitian ini.

Melalui komunitas gamer dan gamer secara individu (yang tidak tergabung dalam komunitas), penulis akan mendapatkan data dengan wujud tindak tutur yang kemudian ditranskripsi ke dalam bentuk teks dialog tertulis. Jumlah dan tipe gamer yang bermacammacam berdasarkan umur, pekerjaan, dan intensitas bermain game online akan menimbulkan data yang sangat banyak dan memungkinkan terjadinya human error pada saat penulis menganalis data. Oleh karena itu, penulis mengerucutkan lagi sumber data tersebut melalui beberapa pembatasan sesuai dengan faktor-faktor yang sudah disebutkan sebelumnya. Pertama, pekerjaan gamer minimal adalah siswa sekolah menengah atas kelas satu dan sederajat sampai dengan gamer yang sudah lulus atau sudah bekerja. Alasan penentuan pekerjaan tersebut karena bagi gamer dengan tingkat pendidikan di bawah sekolah menengah atas, mereka masih kurang dalam hal kompetensi bertutur dan pemahaman kosakata istilah khusus terkait dengan game online yang dimainkan. Hal tersebut kemudian dapat menyulitkan penulis untuk mencari dan menyaring data dalam penelitian ini.

Pembatasan kedua memfokuskan pada intensitas waktu para gamer pada saat memainkan game online. Penulis akan mengambil data tuturan dari mereka yang sering datang di pusat game online (informasi didapatkan melalui penjaga game online sebagai narasumber sekaligus sumber data penunjang) dengan kurun waktu bermain lebih dari dua jam. Alasannya adalah, intensitas bermain yang cukup lama (yaitu dua jam) dan kebiasaan untuk bermain game online berdampak pada interaksi tuturan antargamer sekaligus pengetahuan masing-masing individu tersebut mengenai tindak tutur khas gamer beserta kosakatanya.

Sampel penelitian ini ditentukan berdasarkan purposive sampling. Purposive sampling adalah teknik pengambilan sampel dengan pertimbangan tertentu menurut peneliti dengan cara menentukan subjek atau objek sesuai tujuan. Dengan menggunakan pertimbangan pribadi yang sesuai dengan topik penelitian, peneliti memilih subjek atau objek yang bersifat asertif sebagai unit analisis (Satori dan Komariah, 2010). 
Melalui pendapat tersebut, penulis akan memilih sampel berupa sepuluh game online dengan peringkat teratas melalui referensi dari data sekunder, yaitu majalah yang mengulas perihal game dan internet. Selanjutnya, sampel dipilih sesuai dengan genre game online yang sering dimainkan oleh para gamer di pusat permainan game online tersebut di kota Solo.

Penyediaan data akan menggunakan metode simak dan catat, yaitu menyimak penggunaan bahasa (Sudaryanto, 1993: 133). Menyimak tidak hanya berkaitan dengan data secara lisan saja melainkan juga tertulis yang dimasukkan ke dalam kartu data. Dalam penelitian ini, penulis menyimak pertuturan antar gamer yang terjadi ketika mereka bermain game online sembari mencatat data yang relevan sesuai dengan rumussan masalah. Dalam penyediaan data secara lisan, penulis menggunakan teknik-teknik sebagai berikut.

1. Teknik observasi partisipasi

Teknik ini dilakukan dengan pengamatan terhadap suatu objek yang diteliti, baik secara langsung maupun tidak langsung untuk memperoleh data yang harus dikumpulkan dalam penelitian (Satori dan Komariah, 2010). Terkait dengan penelitian ini, teknik observasi partisipasi dilakukan dengan melakukan penelitian langsung oleh peneliti terhadap komunitas gamer untuk mengamati karakteristik tindak tutur mereka.

2. Teknik wawancara tak terstruktur

Pemerolehan data dari gamer dilakukan dengan cara wawancara secara langsung yang tidak didahului atau dibekali daftar pertanyaan secara rinci atau spesifik. Peneliti berharap memperoleh informasi dari para gamer sealami mungkin.

\section{Teknik elisitasi}

Untuk mendapatkan data yang lengkap, peneliti dapat menggunakan teknik elisitasi (Spolsky, 2003), yaitu satu strategi untuk memancing atau mengarahkan informan dalam memberi informasi yang sebenarnya.

Metode analisis kontekstual yang dipakai dalam menganalisis jenis-jenis tindak tutur beserta fungsinya layak diterapkan dalam penelitian ini. Disebut kontekstual karena analisis data dilakukan terhadap wujud nyata tuturan yang dilakukan oleh penutur tertentu kepada mitra tutur 
tertentu, di tempat dan waktu tertentu, dan suasana atau situasi bertutur tertentu (Edi Subroto: 2008).

Langkah-langkah yang diambil penulis guna melakukan analisis data adalah sebagai berikut. Data yang berasal dari rekaman tuturan komunitas gamer akan dirubah wujudnya menjadi transkrip tertulis. Data tersebut kemudian disajikan, diseleksi, dan dianalisis sesuai konteksnya untuk menemukan jenis dan fungsi dari suatu tindak tutur dengan bantuan pemahaman teori-teori tindak tutur milik Searle dan Kreidler. Analisis data dilakukan hanya pada tindak tutur yang sesuai dengan konteks game online yang sedang dimainkan, baik itu dalam proses persiapan, saat, dan setelah bermain. Hal yang disebut terakhir itu memiliki maksud bahwa penulis tidak akan menganalisis tindak tutur yang terjadi sebagai obrolan belaka antargamer. Data yang tidak dianalisis tersebut nantinya akan bergabung menjadi satu kesatuan dalam wujud data residu. Sebagai langkah selanjutnya, akan ditemukan jenis tindak tutur komunitas gamer yang paling dominan sekaligus alasan munculnya jenis tindak tutur dominan tersebut.

Di dalam transkrip tuturan tersebut akan ditemukan juga kosakata gamer sebagai istilah khusus. Uraian pemahaman terkait istilah khusus akan langsung dilakukan pada analisis data terkait, sedangkan yang kemudian dilakukan adalah penggolongan istilah khusus tersebut sesuai dengan satuan lingual (kata, frasa, atau klausa) dan kelas katanya (nomina, verba, adjektiva, adverbia).

\section{HASIL PENELITIAN DAN PEMBAHASAN}

Hasil yang dapat ditarik dari pembahasan data tindak tutur yang telah dianalisis sebelumnya meliputi rangkuman jenis dan fungsi tindak tutur yang ditemukan, serta istilahistilah khusus yang menyertainya. Penulis menemukan bahwa prosentase kemunculan jenis tindak tutur beserta fungsinya yang dominan, berbeda antara satu lokasi penelitian dengan 
lainnya. Masing-masing pusat game online di tiap kecamatan memiliki ciri khasnya sendiri terkait penggunaan tindak tutur, baik jenis maupun fungsinya.

Pembahasan selanjutnya akan dibagi menjadi tiga sub bab guna menjawab masalah yang sesuai dengan poin pada tujuan penelitian. Sub bab tersebut antara lain menemukan jenis tindak tutur yang sering digunakan sekaligus fungsinya dan istilah khusus yang diimplementasikan oleh peserta tutur saat terjadi komunikasi verbal antar gamer.

\section{Pembahasan Jenis Tindak Tutur Komunitas Gamer Kota Solo}

Jenis tindak tutur yang diklasifikasikan menjadi lima kategori, yaitu asertif, direktif, ekspresif, komisif, dan deklaratif, ditemukan pada data tuturan yang diambil dari masingmasing pusat game online dengan jumlah kemunculan yang berbeda-beda. Pembahasan jenis tindak tutur pada sub bab ini akan dilakukan pada masing-masing kategori sesuai dengan penerapannya dalam tuturan antar gamer.

1. Jenis tindak tutur Asertif

Jenis tindak tutur asertif terdapat pada setiap data tuturan komunitas gamer di kota Solo melalui perwakilan lima game center di masing-masing kecamatan. Dari keseluruhan data tindak tutur yang berjumlah 39, jenis tindak tutur asertif ditemukan di 26 nomor data. Tuturan yang dikelompokkan ke dalam asertif sesuai dengan letaknya dalam nomor data tersebut berjumlah 55 buah, atau setara dengan 24,5\% dari keseluruhan 224 tuturan.

\section{Jenis tindak tutur Direktif}

Keseluruhan nomor data tindak tutur yang terlibat dalam penggunaan jenis tindak tutur direktif adalah 31 buah. Jumlah nomor data jenis tindak tutur direktif jauh lebih banyak apabila dibandingkan dengan jumlah nomor data yang ditemukan pada jenis tindak tutur asertif sebanyak 26 buah. Secara otomatis tuturan yang dikategorikan ke dalam jenis direktif memiliki jumlah yang jauh lebih banyak juga, yaitu 83 tuturan. Jumlah tersebut sama dengan $37,1 \%$ dari jumlah keseluruhan data tuturan. Jenis tindak tutur direktif memiliki jumlah tuturan terbanyak 
daripada jenis tindak tutur lainnya karena gamer cenderung menuturkan kalimat tanya, perintah, atau larangan sebagai ciri khusus direktif.

\subsubsection{Jenis tindak tutur Ekspresif}

Pada bagian tindak tutur ekspresif, penulis menemukan sejumlah tuturan yang terlibat di 22 nomor data. Penyebaran jenis tindak tutur ekspresif terletak pada 37 tuturan, setara dengan $16,5 \%$ dari keseluruhan tuturan yang diamati. Sebagian besar wujud kalimat yang digunakan terkait jenis tindak tutur ekspresif adalah makian karena gamer terbiasa melampiaskan kekesalannya saat bermain dengan cara demikian. Sesuai dengan data yang diperoleh, kata-kata makian diterapkan oleh seluruh tingkat usia, baik pada usia siswa sekolah menengah, mahasiswa, maupun dewasa. Dengan hal ini, penulis dapat menyimpulkan bahwa pelanggaran maksim dan norma kesopanan seringkali dilakukan oleh gamer karena pengaruh lingkungan tempat mereka bermain mendukung terjadinya pelanggaran tersebut. Meskipun demikian, tidak ditemukan konflik antar gamer yang dimungkinkan dapat terjadi akibat adanya pelanggaran maksim dan norma tersebut. Hal itu dikarenakan para gamer sebagai peserta tutur sudah memiliki pemahaman tentang penggunaan makian yang hanya bersifat spontanitas saja tanpa ada maksud untuk ditujukan kepada gamer secara individu.

\subsubsection{Jenis tindak tutur Komisif}

Bentuk tuturan dengan wujud respon menyetujui muncul paling banyak pada tindak tutur komisif. Dialog antar gamer yang terjadi saat mereka melakukan komunikasi tanya jawab terkait strategi permainan menjadi alasan utama terjadinya tuturan dengan jenis komisif. Nomor data yang terlibat pada jenis tindak tutur komisif sejumlah 19. Terkait dengan jumlah tuturan ditemukannya jenis tindak tutur komisif, penulis mencatat 24 tuturan yang terlibat atau sebesar $10,7 \%$.

\subsubsection{Jenis tindak tutur Deklaratif}

Jenis tindak tutur deklaratif sebagai jenis ke lima yang dianalisis pada penelitian ini tersebar hanya pada 8 nomor data. Berikut pada tuturannya, jenis deklaratif terlibat dalam 11 tuturan atau 4,9\% dari keseluruhan jumlah tuturan sebanyak 224. 


\subsubsection{Jenis tindak tutur Verdiktif}

Jenis tindak tutur selanjutnya untuk kategori verdiktif hadir pada 12 nomor data. Perbedaan tipis antara jenis tindak tutur kategori ekspresif dan verdiktif menimbulkan tantangan tersendiri bagi penulis untuk menetapkan jenis tindak tutur sebenarnya yang melekat pada tuturan terkait. Meskipun demikian, peran serta penutur yang tidak terlibat dalam konteks munculnya tuturan untuk jenis verdiktif menjadi acuan utama penentuan kategori ini. Dari keseluruhan 12 nomor data, jenis ini tersebar dalam 14 tuturan atau 6,3\%.

\subsubsection{Jenis tindak tutur Fatis.}

Berdasarkan analisis data tindak tutur komunitas gamer kota Solo, tidak ditemukan sama sekali jenis tindak tutur kategori fatis. Sifat kategori ini yang berguna untuk menyampaikan tuturan dengan kesan hanya untuk mempererat hubungan saja bahkan untuk basa-basi, tidak tepat guna ketika gamer membutuhkan tuturan yang bersifat yang lugas, ringkas, dan langsung. Oleh sebab itu, dari keseluruhan data yang diperoleh, tidak ada satu pun tuturan yang mengandung jenis tindak tutur fatis.

Sesuai dengan uraian jenis tindak tutur di atas, penulis mampu mengurutkan keseringan munculnya penggunaan jenis tindak tutur dari yang paling banyak ke yang paling sedikit. Diperoleh hasil prosentase tertinggi pada jenis tindak tutur direktif $(37,1 \%)$, asertif $(24,5 \%)$, ekspresif (16,5\%), komisif (10,7\%), verdiktif (6,3\%), deklaratif $(4,9 \%)$, dan fatis $(0 \%)$.

Melalui hasil tersebut, simpulan yang dapat ditarik dari interaksi tindak tutur komunitas gamer online di kota Solo mengerucut pada pemilihan jenis tindak tutur direktif sebagai ciri khasnya. Alasan utama kemunculan jenis tindak tutur direktif sebagai jenis yang paling sering digunakan berkaitan erat dengan fungsi tindak tutur khas direktif untuk memberikan perintah, pertanyaan, maupun larangan. Tiga contoh fungsi tersebut merupakan fungsi dari bentuk tuturan yang paling sering digunakan, sekaligus paling efektif, untuk menyampaikan maksud dari gamer saat berinteraksi dengan rekannya sambil memainkan game online. Mereka menerapkan jenis tindak tutur direktif untuk menghemat waktu pengiriman pesan melalui tuturan singkat 
namun jelas, karena sebagian besar konteks terjadinya tuturan adalah pada saat game online sedang dimainkan. Oleh karena itu, tidak memungkinkan bagi mereka untuk menggunakan kalimat lengkap pada tuturannya setiap saat. Selain alasan tersebut, jenis tindak tutur direktif cocok digunakan oleh para gamer karena dalam tuturannya terkandung komunikasi guna menyusun strategi permainan dengan cara saling memberikan perintah atau larangan. Perilaku demikian sangatlah penting bagi mereka untuk menciptakan kerjasama tim yang baik guna memenangkan permainan.

\section{Pembahasan Fungsi Tindak Tutur Komunitas Gamer Kota Solo}

Terdapat berbagai macam fungsi tindak tutur yang digolongkan sesuai dengan jenis tindak tuturnya. Pada sub bab ini, simpulan terkait dengan pembahasan fungsi tindak tutur komunitas gamer kota Solo dapat ditarik sesuai dengan prosentase penggunaan fungsi tindak tutur yang pembahasannya akan dilakukan sesuai dengan jenis tindak tuturnya.

\section{Fungsi Tindak Tutur pada Asertif}

Terkait dengan fungsi tindak tutur, penulis menemukan dua macam fungsi yang terdiri dari fungsi langsung dan tidak langsung. Sebagian besar fungsi tindak tutur dari jenis asertif adalah fungsi langsung karena penuturnya bermaksud menyampaikan informasi secara langsung melalui tuturannya tanpa ada maksud lain yang tersembunyi. Bagian fungsi tindak tutur tidak langsung hanya ditemukan pada tuturan "bentar ni baru mau tak gabungin" (data nomor 11) dan "ilusi ilusi" (data nomor 25) yang keduanya memerlukan pemahaman konteks beserta implikaturnya guna menangkap fungsi tuturan sebenarnya seperti yang sudah dijabarkan. Intensitas penggunaan fungsi tindak tutur untuk menyatakan informasi adalah yang paling banyak ditemukan, yaitu sebanyak 44 kali kemunculan. Peringkat penggunaan fungsi tindak tutur dengan jumlah yang lebih sedikit berturut-turut antara lain fungsi memberikan keterangan (3), memberikan penjelasan (3), mengiyakan perintah (1), menyatakan keputusan (1), menyalahkan (1), menyatakan larangan (1), dan memberikan saran (1). 


\section{Fungsi Tindak Tutur pada Direktif}

Fungsi tindak tutur pada bagian ini dikelompokkan menjadi berbagai kategori. Kategori-kategori tersebut adalah fungsi untuk bertanya (23), memerintah (39), menanyakan pendapat (3), menawarkan bantuan (1), menyampaikan harapan (1), melarang (6), memperingatkan (4), dan menasihati (7). Tampak dengan jelas bahwa pada bagian ini, fungsi memerintah menjadi yang paling dominan di antara fungsi-fungsi lainnya. Penyebab utamanya adalah adanya hierarki kepemimpinan yang secara tersirat diterapkan oleh komunitas game online melalui perintah yang diberikan oleh gamer yang lebih berpengalaman kepada gamer pemula. Faktor usia hanya berperan kecil dalam rangka memberikan perintah antar anggota komunitas gamer, sehingga sangat mungkin terjadi bagi gamer yang lebih muda usianya untuk memberikan perintah kepada gamer dengan usia yang lebih tua tanpa kekhawatiran melanggar maksim kebijaksanaan.

\section{Fungsi Tindak Tutur pada Ekspresif}

Jenis tindak tutur ekspresif yang terdiri dari 24 nomor data dan dibagi menjadi 51 tuturan memunculkan beberapa fungsi tindak tutur. Mereka adalah fungsi memaki (8), menyindir (6), mengeluh (4), menghina (6), mengumpat (13), memprotes (1), memuji (8), mengeritik (2), mengacuhkan (1), meminta maaf (1), dan menyombongkan (1). Sesuai dengan temuan tersebut, dapat dikatakan bahwa gaya bertutur komunitas gamer lebih mengarah pada informal dan tidak menataati prinsip kesantunan beserta maksim-maksimnya. Pernyataan tersebut didukung oleh fungsi tindak tutur bernosi negatif seperti memaki, menyindir, mengeluh, menghina, mengumpat, memprotes, mengeritik, mengacuhkan, dan menyombongkan dengan prosentase penggunaan lebih banyak apabila dibandingkan dengan fungsi bernosi positif layaknya memuji dan meminta maaf.

\section{Fungsi Tindak Tutur pada Komisif}

Varian paling sedikit terkait fungsi tindak tutur yang ditemukan melalui analisis jenis tindak tutur komisif terdiri dari fungsi menolak (3), menyetujui (16), dan berjanji (5). Melalui pengamatan penulis saat pengambilan data, tuturan dengan fungsi menyetujui muncul dengan 
jumlah sedemikian rupa karena konteks terjadinya tuturan adalah pada saat para gamer berkomunikasi untuk saling memberikan pendapat guna menyusun strategi permainan tim. Oleh sebab itu, menyetujui menjadi pilihan tepat bagi mereka ketika opini atau ide dituturkan demi keberhasilan seluruh komunitas.

\section{Fungsi Tindak Tutur pada Deklaratif}

Sekelompok fungsi tindak tutur yang berbeda diungkap dari jenis deklaratif yang hanya terdiri dari 8 nomor data dengan 11 jumlah tuturan di dalamnya. Fungsi-fungsi tersebut adalah memutuskan (1), menunjuk (2), menegaskan (7), dan meminta ijin (1).

\section{Fungsi Tindak Tutur pada Verdiktif}

Kategori jenis tindak tutur verdiktif yang melekat pada sejumlah tuturan yang telah dibahas di atas mengandung beberapa fungsi. Fungsi-fungsi tersebut antara lain memaki (2), menyindir (2), menghina (3), memuji (5), mengeluh (1), dan mengeritik (1).

Berikut adalah prosentase penggunaan kalimat yang di dalamnya terkandung berbagai macam fungsi tindak tutur, diantaranya fungsi menyatakan informasi $(19,6 \%)$, memerintah $(17,3 \%)$, bertanya $(10,2 \%)$, menyetujui $(7,1 \%)$, mengumpat $(5,8 \%)$, memuji $(3,6 \%)$, memaki $(3,6 \%)$, menasihati $(3,2 \%)$, menegaskan $(3,2 \%)$, melarang $(3,2 \%)$, menyindir $(2,8 \%)$, menghina $(2,8 \%)$, berjanji $(2,2 \%)$, memperingatkan $(1,8 \%)$, mengeluh $(1,8 \%)$, memberikan keterangan $(1,3 \%)$, menanyakan pendapat $(1,3 \%)$, memberikan penjelasan $(1,3 \%)$, menolak $(1,3 \%)$, mengeritik $(0,9 \%)$, menunjuk $(0,9 \%)$, mengiyakan perintah $(0,4 \%)$, menyatakan keputusan $(0,4 \%)$, menyalahkan $(0,4 \%)$, memberikan saran $(0,4 \%)$, menawarkan bantuan $(0,4 \%)$, menyampaikan harapan $(0,4 \%)$, memprotes $(0,4 \%)$, mengacuhkan $(0,4 \%)$, meminta maaf $(0,4 \%)$, menyombongkan $(0,4 \%)$, memutuskan $(0,4 \%)$, dan meminta ijin $(0,4 \%)$.

\section{Pembahasan Istilah Khusus Komunitas Gamer Kota Solo}

Pembahasan tentang istilah khusus yang digunakan oleh peserta tutur sebagai anggota komunitas gamer di kota Solo akan diuraikan pada bagian ini. Uraian lebih lanjut mengenai 
makna, kelas kata, dan contoh penggunaannya dalam kalimat dirasa perlu untuk dilakukan guna mencapai pemahaman menyeluruh terhadap penelitian ini.

Istilah khusus yang dapat digolongkan ke dalam kosakata register komunitas gamer berasal dari bermacam sumber bahasa, termasuk di dalamnya antara lain Bahasa Inggris dan Bahasa Jawa. Sebagian besar istilah khusus dalam Bahasa Inggris berasal dari kosakata game online yang dimainkan, sedangkan istilah khusus dalam Bahasa Jawa berkaitan erat dengan latar belakang peserta tutur yang hampir semuanya berasal dari suku Jawa dengan penguasaan Bahasa Jawa aktif dan pasif. Berikut adalah tabel yang secara terperinci membahas istilah khusus yang ditemukan dalam data tindak tutur komunitas gamer Kota Solo.

Tabel Istilah Khusus Komunitas Gamer Kota Solo

\begin{tabular}{|c|c|c|c|c|}
\hline $\begin{array}{l}\text { No. } \\
\text { Data }\end{array}$ & Istilah Khusus & Makna & $\begin{array}{l}\text { Kelas } \\
\text { Kata }\end{array}$ & $\begin{array}{c}\text { Contoh Penggunaan } \\
\text { dalam Kalimat }\end{array}$ \\
\hline 1 & $\begin{array}{l}\text { Wols } \\
\text { Searching }\end{array}$ & $\begin{array}{l}\text { Fitur dalam game online } \\
\text { untuk menunggu pemain lain } \\
\text { sebelum memulai permainan } \\
\text { Sabar/ pelan-pelan } \\
\text { Fitur dalam game online } \\
\text { untuk mencari room atau } \\
\text { gamer lainnya }\end{array}$ & $\begin{array}{l}\text { verba } \\
\text { verba }\end{array}$ & $\begin{array}{l}\text { "Tunggu apa lagi? Ayo } \\
\text { mulai, roomnya sudah siap." } \\
\text { "Wols, baru juga mulai, sudah } \\
\text { mau ganti permainan." } \\
\text { "Pakai searching saja biar } \\
\text { cepat ketemu." }\end{array}$ \\
\hline 2 & Gift & $\begin{array}{l}\text { Fitur dalam game online } \\
\text { untuk menghadiahkan barang } \\
\text { kepada pemain lain }\end{array}$ & nomina & $\begin{array}{l}\text { "Saya dapat gift nih dari } \\
\text { gamer dari Bandung." }\end{array}$ \\
\hline 3 & Tero & $\begin{array}{l}\text { Akronim dari terrorist untuk } \\
\text { merujuk pada tokoh penjahat } \\
\text { dalam game online Point } \\
\text { Blank }\end{array}$ & nomina & $\begin{array}{l}\text { "Saya pilih main pakai tero } \\
\text { saja ya biar imbang timnya." }\end{array}$ \\
\hline \multirow[t]{3}{*}{4} & Double kill & $\begin{array}{l}\text { Gelar yang diterima pemain } \\
\text { ketika berhasil membunuh } \\
\text { dua musuh secara berturut- } \\
\text { turut }\end{array}$ & adjektiva & $\begin{array}{l}\text { "Hebat kamu bisa dapat } \\
\text { double kill. Padahal } \\
\text { musuhnya susah banget." }\end{array}$ \\
\hline & $\begin{array}{l}\text { Mbokong } \\
\text { Cacad }\end{array}$ & $\begin{array}{l}\text { Membunuh musuh dari } \\
\text { belakang } \\
\text { Gelar yang diterima pemain } \\
\text { karena gaya permainannya } \\
\text { yang tidak bagus }\end{array}$ & $\begin{array}{c}\text { verba } \\
\text { adjektiva }\end{array}$ & $\begin{array}{l}\text { "Mbokong saja kalau bisa, } \\
\text { biar tidak ketahuan musuh." } \\
\text { "Cacad banget sih sampai } \\
\text { mati } 20 \text { kali." }\end{array}$ \\
\hline & $\begin{array}{l}\text { Cover } \\
\text { Diamond }\end{array}$ & $\begin{array}{l}\text { Sebutan lain untuk senjata } \\
\text { granat pada game online } \\
\text { Point Blank } \\
\text { Melindungi } \\
\text { Gelar yang diterima pemain }\end{array}$ & $\begin{array}{c}\text { verba } \\
\text { adjektiva }\end{array}$ & $\begin{array}{l}\text { "Punya telek kan? Lempar } \\
\text { tuh sebelah sana! Musuhnya } \\
\text { sembunyi di situ." } \\
\text { "Jangan kejauhan nyari } \\
\text { musuhnya, cover saya ya." } \\
\text { "Lihat nih, saya sudah }\end{array}$ \\
\hline
\end{tabular}




\begin{tabular}{|c|c|c|c|c|}
\hline $\begin{array}{l}\text { No. } \\
\text { Data }\end{array}$ & Istilah Khusus & Makna & $\begin{array}{l}\text { Kelas } \\
\text { Kata }\end{array}$ & $\begin{array}{c}\text { Contoh Penggunaan } \\
\text { dalam Kalimat }\end{array}$ \\
\hline & & $\begin{array}{l}\text { game online Point Blank } \\
\text { apabila telah mencapai } \\
\text { peringkat tertentu }\end{array}$ & & $\begin{array}{l}\text { diamond lho. Hasil main dua } \\
\text { bulan nih." }\end{array}$ \\
\hline 6 & Flashbang & $\begin{array}{l}\text { Salah satu senjata tipe granat } \\
\text { di game online Point Blank }\end{array}$ & nomina & $\begin{array}{l}\text { "Lempar pakai flashbang } \\
\text { dulu baru serbu musuhnya." }\end{array}$ \\
\hline 7 & $G G$ & $\begin{array}{l}\text { Good gamel pujian yang } \\
\text { ditujukan kepada gamer } \\
\text { karena bermain dengan baik }\end{array}$ & adjectiva & $\begin{array}{l}\text { "GG semuanya. Jangan } \\
\text { sampai gak menang lho habis } \\
\text { ini." }\end{array}$ \\
\hline 8 & Password & $\begin{array}{l}\text { Memasuki permainan dengan } \\
\text { menggunakan nama } \\
\text { pengguna terlebih dahulu } \\
\text { Kata sandi }\end{array}$ & nomina & $\begin{array}{l}\text { "Aduh, gagal login nih. } \\
\text { Sepertinya } \\
\text { internetnya putus." } \\
\text { "Jangan pakai password } \\
\text { tanggal lahir, bahaya itu." }\end{array}$ \\
\hline 11 & Rede & $\begin{array}{l}\text { Pertarungan dalam game } \\
\text { online empat pemain lawan } \\
\text { empat pemain } \\
\text { Keadaan siap untuk bermain }\end{array}$ & adjektiva & $\begin{array}{l}\text { "Sudah cukup nih orangnya, } \\
\text { ganti ke } 4 x 4 \text { saja ya." } \\
\text { "Ayo cepetan rede, keburu } \\
\text { malam ini gak main main." }\end{array}$ \\
\hline 12 & $\begin{array}{l}\text { Teol } \\
\text { Keias } \\
\text { TB } \\
\text { Benti } \\
\text { Colok }\end{array}$ & $\begin{array}{l}\text { Teolia/ salah satu hero dalam } \\
\text { game online Avalon } \\
\text { Salah satu hero dalam game } \\
\text { online Avalon } \\
\text { Tahan body/ karakter hero } \\
\text { dengan daya tahan tinggi } \\
\text { Bentilus/ salah satu hero } \\
\text { dalam game online Avalon } \\
\text { Penambahan kemampuan } \\
\text { hero dengan memasukkan } \\
\text { bahan persyaratan tertentu } \\
\text { Mendukung/ tipe hero } \\
\text { dengan tugas mendukung } \\
\text { temannya di pertempuran } \\
\text { Adelial salah satu hero dalam } \\
\text { game online Avalon }\end{array}$ & $\begin{array}{l}\text { nomina } \\
\text { nomina } \\
\text { adjektiva } \\
\text { nomina } \\
\text { verba }\end{array}$ & $\begin{array}{l}\text { "Pilih pakai Teol saja lah." } \\
\text { "Jangan pakai Keias lagi } \\
\text { napa?" } \\
\text { "Maju duluan gih, kamu kan } \\
\text { pakai hero TB." } \\
\text { "Benti saja yang dipakai, } \\
\text { hebat dia." } \\
\text { "Suka banget aku sama hero } \\
\text { ini, tak colok ah biar tambah } \\
\text { hebat." } \\
\text { "Heromu jangan lupa dipakai } \\
\text { buat support kita lho." } \\
\text { "Mau coba pakai Adel } \\
\text { ni,susah tidak ya?" }\end{array}$ \\
\hline 14 & $\begin{array}{l}\text { Tower } \\
\text { War } \\
\text { Farming }\end{array}$ & $\begin{array}{l}\text { Membunuh musuh untuk } \\
\text { meningkatkan kemampuan } \\
\text { hero yang dimainkan } \\
\text { Menara pertahanan } \\
\text { Perang/ pertempuran } \\
\text { Bertani/ berburu musuh } \\
\text { untuk mencari pengalaman } \\
\text { hero sebanyak-banyaknya }\end{array}$ & $\begin{array}{l}\text { nomina } \\
\text { nomina } \\
\text { verba }\end{array}$ & $\begin{array}{l}\text { "Saya leveling dulu biar bisa } \\
\text { ikut war." } \\
\text { "Awas, jangan dekat-dekat } \\
\text { tower daerah situ, bahaya." } \\
\text { "War barusan seru banget } \\
\text { mas, akhirnya bisa menang." } \\
\text { "Gak farming dulu? Heromu } \\
\text { masih belum hebat lho." }\end{array}$ \\
\hline 15 & $\begin{array}{l}\text { Makuma } \\
\text { Level } \\
\text { Raiksha }\end{array}$ & $\begin{array}{l}\text { Karakter bantuan yang dapat } \\
\text { dipanggil oleh Teolia } \\
\text { Tingkatan kemampuan hero } \\
\text { Salah satu hero dalam game } \\
\text { online Avalon }\end{array}$ & $\begin{array}{l}\text { nomina } \\
\text { nomina } \\
\text { nomina }\end{array}$ & $\begin{array}{l}\text { "Teol, keluarin Makuma } \\
\text { dong. Bantu sini ya." } \\
\text { "Sudah level sepuluh tapi } \\
\text { masih belum kuat juga." } \\
\text { "Kenapa maunya pakai } \\
\text { Raiksha terus sih bang?" }\end{array}$ \\
\hline
\end{tabular}




\begin{tabular}{|c|c|c|c|c|}
\hline $\begin{array}{l}\text { No. } \\
\text { Data }\end{array}$ & Istilah Khusus & Makna & $\begin{array}{l}\text { Kelas } \\
\text { Kata }\end{array}$ & $\begin{array}{c}\begin{array}{c}\text { Contoh Penggunaan } \\
\text { dalam Kalimat }\end{array} \\
\end{array}$ \\
\hline & Ulti & Ultimatel jurus pamungkas & nomina & $\begin{array}{l}\text { "Ulti belum siap sudah mati } \\
\text { duluan, nasib nasib." }\end{array}$ \\
\hline 16 & $\begin{array}{l}\text { Heal } \\
\text { Golem }\end{array}$ & $\begin{array}{l}\text { Kemampuan hero untuk } \\
\text { menyembuhkan } \\
\text { Karakter netral yang tidak } \\
\text { memihak kubu manapun di } \\
\text { game online Avalon }\end{array}$ & $\begin{array}{l}\text { verba } \\
\text { nomina }\end{array}$ & $\begin{array}{l}\text { "Tinggal dikit lagi mati ini. } \\
\text { Minta heal dong." } \\
\text { "Golem tuh letaknya di peta } \\
\text { sebelah mana ya?" }\end{array}$ \\
\hline 17 & $\begin{array}{l}\text { Def } \\
\text { Barrack }\end{array}$ & $\begin{array}{l}\text { Defend/ bertahan } \\
\text { Tempat pembuatan prajurit }\end{array}$ & $\begin{array}{l}\text { verba } \\
\text { nomina }\end{array}$ & $\begin{array}{llr}\text { "Gawat. } & \text { Semua } & \text { musuh } \\
\text { menyerang, def!" } & \\
\text { "Kalau barracknya } & \text { sudah } \\
\text { hancur pasti lebih } & \text { mudah } \\
\text { menang tim kita." } & \\
\text { "Jangan serang } & \text { duluan, } \\
\text { tunggu sampai } & \text { delayku } \\
\text { habis." } & & \\
\end{array}$ \\
\hline 18 & Сири & $\begin{array}{l}\text { Gelar yang diterima pemain } \\
\text { karena bermain buruk }\end{array}$ & adjektiva & $\begin{array}{l}\text { "Ya ampun cupunya. Cara } \\
\text { beli senjata saja tanya." }\end{array}$ \\
\hline 19 & Asep & $\begin{array}{l}\text { Asap/ kemampuan salah satu } \\
\text { hero dalam game online } \\
\text { DOTA } 2\end{array}$ & nomina & $\begin{array}{l}\text { "Biar gak ketahuan musuh ya } \\
\text { dipake asepnya." }\end{array}$ \\
\hline 21 & Manuk & $\begin{array}{l}\text { Burung/ karakter pembantu } \\
\text { untuk mengirimkan barang } \\
\text { dalam game online DOTA } 2\end{array}$ & nomina & $\begin{array}{l}\text { "Tidak perlu kembali markas, } \\
\text { pakai kurir manuk saja." }\end{array}$ \\
\hline & $S K$ & $\begin{array}{l}\text { Skeleton king/ Salah satu } \\
\text { hero dalam game online } \\
\text { DOTA } 2\end{array}$ & nomina & $\begin{array}{l}\text { "Jangankan tahu jurusnya, } \\
\text { pakai } S K \text { saja belum pernah." }\end{array}$ \\
\hline & Akhasa & $\begin{array}{l}\text { Salah satu hero dalam game } \\
\text { online DOTA } 2\end{array}$ & nomina & $\begin{array}{l}\text { "Kalau mau pilih hero } \\
\text { dengan jurus mematikan, } \\
\text { Akhasa saja" }\end{array}$ \\
\hline 22 & Miss & $\begin{array}{l}\text { Luput/ serangan tidak } \\
\text { mengenai sasaran }\end{array}$ & adjektiva & $\begin{array}{l}\text { "Mainnya yang serius dong. } \\
\text { Dari tadi kok miss terus." }\end{array}$ \\
\hline 23 & Orchid & $\begin{array}{l}\text { Anggrek/ benda untuk } \\
\text { memperkuat hero dalam } \\
\text { game online DOTA } 2 \\
\text { Rikimarul salah satu hero } \\
\text { dalam game online DOTA } 2\end{array}$ & nomina & $\begin{array}{l}\text { "Sudah mau beli orchid? } \\
\text { Cepatnya, itu kan barang } \\
\text { mahal." } \\
\text { "Mau coba pakai Riki boleh } \\
\text { kan kak?" }\end{array}$ \\
\hline 24 & Fortif & $\begin{array}{l}\text { Mengabaikan/ membunuh } \\
\text { atau menghancurkan } \\
\text { bangunan sendiri agar musuh } \\
\text { tidak mendapatkan apa-apa } \\
\text { Fortify/ melindungi seluruh } \\
\text { bangunan kubu sendiri } \\
\text { selama beberapa saat dengan } \\
\text { kemampuan tim }\end{array}$ & verba & $\begin{array}{l}\text { "Daripada musuh levelnya } \\
\text { nambah gara-gara hancurin } \\
\text { tower, di deny saja lah." } \\
\text { "Fortif sana cepetan! Bentar } \\
\text { lagi hancur nih markas kita." }\end{array}$ \\
\hline 25 & $\begin{array}{l}\text { Ilusi } \\
\text { Cacing }\end{array}$ & $\begin{array}{l}\text { Tipuan yang berwujud } \\
\text { kembaran dari hero } \\
\text { Anak buah hero Venomancer } \\
\text { game online DOTA } 2 \text { yang } \\
\text { berbentuk seperti cacing } \\
\text { Kemampuan hero game }\end{array}$ & $\begin{array}{l}\text { nomina } \\
\text { nomina }\end{array}$ & $\begin{array}{l}\text { "Ngapain nyerang dia, ilusi } \\
\text { itu." } \\
\text { "Bunuh cacingnya sekarang! } \\
\text { Ganggu saja tu cacing." } \\
\text { "Habis kena teror langsung }\end{array}$ \\
\hline
\end{tabular}




\begin{tabular}{|c|c|c|c|c|}
\hline $\begin{array}{l}\text { No. } \\
\text { Data }\end{array}$ & Istilah Khusus & Makna & $\begin{array}{l}\text { Kelas } \\
\text { Kata }\end{array}$ & $\begin{array}{c}\text { Contoh Penggunaan } \\
\text { dalam Kalimat }\end{array}$ \\
\hline & & $\begin{array}{l}\text { online DOTA } 2 \text { yang bisa } \\
\text { melemahkan lawannya }\end{array}$ & & dikeroyok. Matilah aku." \\
\hline 26 & Medusa & $\begin{array}{l}\text { Salah satu hero dalam game } \\
\text { online DOTA } 2\end{array}$ & nomina & $\begin{array}{l}\text { "Kiri ada Medusa, kanan ada } \\
\text { musuh lainnya. Gimana bisa } \\
\text { lari?" }\end{array}$ \\
\hline 28 & $\begin{array}{l}\text { Line } \\
\text { Killer }\end{array}$ & $\begin{array}{l}\text { Gelar yang diterima pemain } \\
\text { karena gaya permainannya } \\
\text { yang tidak bagus } \\
\text { Garis/ jalur pertempuran } \\
\text { pada game online DOTA } 2 \\
\text { Pembunuh/ peran hero untuk } \\
\text { membunuh musuh }\end{array}$ & $\begin{array}{l}\text { nomina } \\
\text { nomina }\end{array}$ & $\begin{array}{l}\text { "Lain kali tidak mau saya } \\
\text { main sama kroco seperti } \\
\text { kamu. Kalah melulu." } \\
\text { "Pindah line tengah saja yuk, } \\
\text { di sini banyak musuhnya." } \\
\text { "Kalau hero itu paling cocok } \\
\text { dijadikan killernya." }\end{array}$ \\
\hline 30 & $\begin{array}{l}\text { Skill } \\
\text { Shadow } \\
\text { Assassin } \\
\text { Damage } \\
\text { Kill }\end{array}$ & $\begin{array}{l}\text { Rangkaian serangan yang } \\
\text { dilancarkan bertubi-tubi pada } \\
\text { game online Lost Saga } \\
\text { Kemampuan } \\
\text { Salah satu hero dalam game } \\
\text { online Lost Saga } \\
\text { Tingkat kerusakan } \\
\text { Membunuh }\end{array}$ & $\begin{array}{l}\text { nomina } \\
\text { nomina } \\
\text { nomina } \\
\text { verba }\end{array}$ & $\begin{array}{l}\text { "Combo sampai } 12 \text { runtutan? } \\
\text { Dia pasti sudah sangat ahli." } \\
\text { "Penguasaan penggunaan } \\
\text { skillnya jauh di atas rata- } \\
\text { rata." } \\
\text { "Latihan menyerang saja dulu } \\
\text { pakai Shadow Assassin." } \\
\text { "Tambah damagenya pakai } \\
\text { senjata ini lho." } \\
\text { "Yes. Akhirnya aku bisa kill } \\
\text { musuh terkuat itu." }\end{array}$ \\
\hline 31 & Mafia & $\begin{array}{l}\text { Salah satu hero dalam game } \\
\text { online Lost Saga }\end{array}$ & nomina & $\begin{array}{l}\text { "Bagaimana dengan Mafia? } \\
\text { Pakai ini mau tidak?" }\end{array}$ \\
\hline 32 & $\begin{array}{l}\text { Hit } \\
\text { Counter attack } \\
\text { Stun }\end{array}$ & $\begin{array}{l}\text { Serangan yang mengenai } \\
\text { sasaran } \\
\text { Membalas serangan } \\
\text { Tercengang/ kondisi tidak } \\
\text { bisa bergerak setelah terkena } \\
\text { kemampuan musuh } \\
\text { Gelar yang diterima pemain } \\
\text { karena gaya permainannya } \\
\text { yang sangat bagus } \\
\text { Death time/ waktu sisa untuk } \\
\text { kembali ke pertempuran } \\
\text { setelah karakternya tewas } \\
\text { Mendukung/ tipe hero } \\
\text { dengan tugas mendukung } \\
\text { temannya di pertempuran }\end{array}$ & $\begin{array}{l}\text { verba } \\
\text { verba } \\
\text { verba }\end{array}$ & $\begin{array}{l}\text { "Sembunyi dulu di sini, } \\
\text { begitu siap langsung hit } \\
\text { musuh." } \\
\text { "Kalau menghindari serangan } \\
\text { susah, pakai counter attack." } \\
\text { "Biar saya yang stun dia, } \\
\text { langsung hajar ya habis itu." } \\
\text { "Saya dulu dilatih sama orang } \\
\text { itu. Dewa banget dia } \\
\text { mainnya." } \\
\text { "Tunggu dulu, DTku sudah } \\
\text { hampir habis nih. Kita serang } \\
\text { sekaligus." } \\
\text { "Musuh sudah mati semua. } \\
\text { Lanjut ke markas utama saya } \\
\text { back up dari belakang." }\end{array}$ \\
\hline 35 & $\begin{array}{l}\text { Char } \\
\text { Warrior }\end{array}$ & $\begin{array}{l}\text { Fasilitas pada game online } \\
\text { untuk melakukan transaksi } \\
\text { jual beli } \\
\text { Characterl hero yang } \\
\text { digunakan dalam permainan } \\
\text { Salah satu hero dalam game } \\
\text { online Dragon Nest }\end{array}$ & $\begin{array}{l}\text { nomina } \\
\text { nomina }\end{array}$ & $\begin{array}{l}\text { "Saya baru saja dari item } \\
\text { mall. Ternyata banyak barang } \\
\text { yang diskon lho." } \\
\text { "Kalau memberikan nama ke } \\
\text { char harus yang bagus ya." } \\
\text { "Sekali-kali saya mau pake } \\
\text { warrior. Bagus tidak ya?" }\end{array}$ \\
\hline
\end{tabular}




\begin{tabular}{|c|c|c|c|c|}
\hline $\begin{array}{l}\text { No. } \\
\text { Data }\end{array}$ & Istilah Khusus & Makna & $\begin{array}{l}\text { Kelas } \\
\text { Kata }\end{array}$ & $\begin{array}{c}\text { Contoh Penggunaan } \\
\text { dalam Kalimat }\end{array}$ \\
\hline & Del & Delete/ hapus & verba & $\begin{array}{l}\text { "Barang di tempat } \\
\text { penyimpanan } \\
\text { menumpuk, del saja OK?" }\end{array}$ \\
\hline 36 & $\begin{array}{l}\text { Cap } \\
\text { Sea Dragon } \\
+8\end{array}$ & $\begin{array}{l}\text { Duel/ pemain versus pemain } \\
\text { Level kemampuan maksimal } \\
\text { dari hero } \\
\text { Lokasi misi pada game } \\
\text { online Dragon Nest yang } \\
\text { sangat susah diselesaikan } \\
\text { Keterangan untuk barang } \\
\text { yang sudah dimutakhirkan } \\
\text { sebanyak } 8 \text { tingkatan. }\end{array}$ & $\begin{array}{c}\text { adjektiva } \\
\text { nomina }\end{array}$ & $\begin{array}{l}\text { "Kamu yakin nantang saya } \\
P V P \text { ? Levelmu masih rendah } \\
\text { kan?" } \\
\text { "Satu level lagi bakalan cap } \\
\text { aku. Jadi gak sabar." } \\
\text { "Coba taklukkan sea dragon } \\
\text { berani kak? Ayo langsung } \\
\text { habis ini." } \\
\text { "Tetap saja susah ini } \\
\text { mengalahkan raja monster } \\
\text { meskipun sudah }+8 \text { semua. }\end{array}$ \\
\hline 28 & Archer & $\begin{array}{l}\text { Salah satu hero dalam game } \\
\text { online Dragon Nest }\end{array}$ & Nomina & $\begin{array}{l}\text { "Kalau suka pertempuran } \\
\text { jarak jauh pakai saja } \text { archer." }\end{array}$ \\
\hline
\end{tabular}

Berbagai macam fungsi tindak tutur yang ditemukan melalui interaksi verbal komunitas gamer di kota Solo menegaskan bahwa suatu komunitas yang dianggap minoritas di lingkungan masyarakat ternyata memiliki kekayaan olah kata dan kalimat. Mereka menggunakan kemampuannya untuk mengkoordinasikan gerak motorik penggunaan mouse dan keyboard sembari berinteraksi dengan gamer lainnya untuk mencapai keberhasilan serta kesuksesan tim dalam memenangkan permainan game online. Dalam komunitas tersebut, ditemukan juga individu yang berperan sebagai ketua dan bawahannya dengan tugas masing-masing. Dalam usahanya untuk menjadi komunitas gamer yang dianggap hebat, kemampuan berbahasa anggota komunitas tidak luput dari syarat utamanya karena hal itu sangat menentukan timbulnya komunikasi dalam rangka menjuarai suatu permainan game online yang pemainnya tidak hanya berasal dari kota Solo, melainkan juga dari kota-kota lainnya.

\section{DAFTAR PUSTAKA}

Austin, J.L. 1962. How to do Thing with Word. New York: Oxford University Press

Chaer, Abdul dan Leonie Agustina. 2004. Sosiolinguistik: Perkenalan Awal. Jakarta: Rineka Cipta.

Fishman, J.A. 1975. Sociolinguistics: a Brief Introduction. Massachusetts: Newbury Rowley. 
George, F.H. 1964. Semantics. London: The English University Press Ltd.

Gunarwan, Asim. 1994. "Kesantunan Negatif di Kalangan Dwibahasawan Indonesia- Jawa di Jakarta: Kajian Sosiopragmatik” dalam PELLBA 7

Muhadjir, Noeng. 1990. Metodologi Penelitian Kualitatif. Yogyakarta: Rake Sarasin

Satori dan Komariah. 2010. Metodologi Penelitian Kualitatif. Bandung: Alfabeta.

Searle, J.R. 1969. Speech Act. London: Cambridge University Press 1974. Speech Acts: an Essay in the Philosophy of Language. London: Cambridge University Press

Subroto, Edi. 2008. Dalam Kelana Bahana Sang Bahasawan: Persembahan untuk Prof. Soenjono Dardjowidjojo, Ph.D., dalam rangka ulang tahunnya yang ke -70. Jakarta: Universitas Katolik Indonesia Atmajaya

Spolsky, Bernard. 2003. Sociolinguistics. Oxford: Oxford University Press

Sudaryanto. 1993. Metode dan Aneka Teknik Analisis Bahasa: Pengantar Penelitian Wahana Kebudayaan secara Linguistis. Yogyakarta: Duta Wacana University Press

Suwito. 1983. Pengantar Awal Sosiolinguistik: Teori dan Problema. Surakarta: Henary Offset.

Trudgill, Peter. 2002. Sociolinguistic Variation and Change. Edinburg: Edinburg University Press.

Wardhaugh, Ronald. 1977. Introduction to Linguistics. Virginia: McGraw-Hill. 